\title{
CRIME E GLOBALIZAÇÃO: REFLEXÕES SOBRE CRIMES \\ TRANSNACIONAIS E A COOPERAÇÃO JURÍDICA INTERNACIONAL NA CONTEMPORANEIDADE ${ }^{1}$
}

CRIME AND GLOBALIZATION: REFLECTIONS ON TRANSNATIONAL CRIMES AND INTERNATIONAL LEGAL COOPERATION IN CONTEMPORANEITY

Caíque Ribeiro Galícia Doutorando em Ciências Criminais (PUCRS) com período de sanduíche na Universitá degli Studi di Bologna, Italia. Mestre em Ciências Criminais pela PUCRS (2014). Membro do IBRASPP. Professor de cursos de graduação e pósgraduação. Bolsista CAPES/PDSE - Edital 19/2016. Campo Grande/MS.caiquerg@hotmail.com

RESUMO: O presente trabalho apresenta algumas considerações sobre a manifestação do fenômeno da globalização e suas interferências na dinâmica de uma nova forma de criminalidade, denominada transnacional. Nesse panorama, superada essa primeira etapa, expõe os principais contornos conceituais acerca da cooperação jurídica internacional em matéria penal, pois é a ferramenta processual útil para cumprir o propósito da persecução penal tanto permitindo a colheita de dados para acusação como assegurando os direitos fundamentais do acusado. Desta forma, o objetivo principal foi apresentar os standards conceituais dos institutos mencionados, permitindo o desenvolvimento de novas pautas de pesquisa científica para o tema. Metodologicamente o trabalho foi orientado a partir da análise bibliográfica desde uma visão complexa e transdisciplinar.

PALAVRAS-CHAVE: Globalização. Processo Penal. Cooperação Jurídica Internacional. Crimes Transnacionais. Crimes Internacionais.

ABSTRACT: The present work presents some considerations about the manifestation of the phenomenon of globalization and its interferences in the dynamics of a new form of

\footnotetext{
${ }^{1}$ Artigo recebido em 30/08/2017 e aprovado em 13/11/2017.
} 
crime, denominated transnational. In this panorama, after this first step, it exposes the main conceptual contours about international legal cooperation in criminal matters, since it is the procedural tool useful to fulfill the purpose of the criminal prosecution, allowing both the collection of data for prosecution and assuring the fundamental rights of the accused . In this way, the main objective was to present the conceptual standards of the institutes mentioned, allowing the development of new scientific research guidelines for the theme. Methodologically the work was oriented from the bibliographical analysis from a complex and transdisciplinary view.

KEYWORDS: Globalization. Criminal Procedure. International Cooperation. Transnational crimes. International crimes.

SUMÁRIO: Consideraç̃os Iniciais. 1. Crime e Globalização: uma análise transdisciplinar. 2. O caráter transnacional e internacional dos crimes: aproximações e afastamentos teóricos. 3. A cooperação internacional como instrumento fundamental na persecução penal contemporânea. Considerações Finais.

\section{Considerações Iniciais:}

O presente trabalho discorre sobre a dinâmica da criminalidade transnacional e a cooperação jurídica internacional como ferramenta necessária para o seu enfrentamento. $\mathrm{O}$ contexto em que se insere essa discussão perpassa uma análise do fenômeno da globalização como importante fator na ressignificação de conceitos clássicos relacionados com o direito criminal, também como fator catalisador de um processo de transnacionalização da criminalidade, tanto organizada quanto a dita "comum".

Para tanto, objetiva-se traçar algumas linhas gerais de compreensão conceitual acerca do fenômeno da globalização, estabelecendo a premissa de que o mesmo é responsável por uma alteração significativa na dinâmica da criminalidade contemporânea. Ao mesmo tempo, pretende-se esclarecer que, ao contrário do que comumente se propaga, a globalização não é responsável pelo "fim das fronteiras", mas muito pelo contrário. Atualmente se observa um reforço das fronteiras nacionais, o que é o fator primordial para 
o sucesso das operações da criminalidade transnacional, valendo-se dos limites da soberania e da jurisdição em busca da otimização dos resultados ilícitos.

Após a apresentação desse contexto geral da globalização e reflexos para o direito criminal, serão expostos standards conceituais envolvendo a diferença entre criminalidade internacional e transnacional, objetivando-se o esclarecimento das diferenças substancias entre os dois institutos. Para isso, a segunda parte do trabalho traz o enfoque terminológico para expor os afastamentos conceituais do que se compreende criminalidade transnacional e internacional, embora ambas envolvam a cooperação internacional na persecução penal, é preciso demarcar os limites conceituais de cada uma delas.

Por fim, a terceira parte do artigo representa o ponto de encontro entre o cenário contemporâneo marcado pela globalização e a dinâmica da criminalidade transnacional, de maneira que a cooperação jurídica internacional em matéria penal representa, atualmente, a principal ferramenta para a persecução penal desse fenômeno. Todavia, por ainda ser um instituto jurídico consideravelmente novo, o objetivo principal é trazer as principais ideias conceituais a fim de fomentar novas pautas de pesquisa.

Para a construção do trabalho foram utilizados também autores de áreas do conhecimento diversas do Direito, essa escolha deve-se ao diálogo transdisciplinar (como método de pesquisa) e tem como objetivo buscar se aprofundar na complexidade da manifestação do fenômeno em contrapartida à lógica reducionista e pseudo neutra da ciência clássica. Todavia, o trabalho não pretende, de forma alguma, esgotar o tema, mas apresentar uma visão geral do panorama atual, podendo servir de baliza para outros desenvolvimentos científicos específicos sobre o tema.

\section{Crime e Globalização: uma análise transdisciplinar.}

A história da humanidade é a história da evolução da técnica ${ }^{2}$. Perpassando as ferramentas mais rústicas de caça e coleta até a realidade contemporânea traduzida no constante e cada vez mais veloz aprimoramento dos smartphones ${ }^{3}$, o desenvolvimento da

\footnotetext{
${ }^{2}$ A esse respeito, o filme "2001: uma odisseia no espaço" (Stanley Kubrick, 1968), em sua primeira parte, denominada The dawn of $\mathrm{Man}^{2}$, bem ilustra tal desenvolvimento: desde o uso de um simples osso como ferramenta de combate até a chegada do ser humano no espaço sideral.

${ }^{3}$ E a respeito do Direito Penal, "todos sabemos que nada nem ninguém pára(sic) o caudal do rio da história e que o direito penal não é nem nunca foi margem desse rio, antes força vivificadora da torrente de vida, colectiva e individual, que os homens e as mulheres, ao longo de milénios, foram construindo e que, ao fim e
} 
Revista Eletrônica de Direito Processual - REDP.

Rio de Janeiro. Ano 12. Volume 19. Número 1. Janeiro a Abril de 2018

Periódico Quadrimestral da Pós-Graduação Stricto Sensu em Direito Processual da UERJ

Patrono: José Carlos Barbosa Moreira (in mem.). ISSN 1982-7636. pp. 35-61

www.redp.uerj.br

técnica é normalmente associado ao rompimento da dependência dos ciclos da natureza

(regime das águas, secas, crescimento das plantas, etc.) em prol de uma considerável autonomia e expansão dos domínios da espécie humana.

Como consequência, revela-se uma estreita relação entre ser humano-técnicanatureza formando a tríade que marca todos os estágios de mudanças significativas na sociedade $^{4}$. Afinal, atualmente um dos grandes problemas da humanidade ainda é encontrar o ponto de equilíbrio entre a implementação da técnica a favor do "melhor viver" do ser humano e a imprevisibilidade da reação do meio ambiente ${ }^{5}$. E é nesse panorama geral que faz sentido refletir sobre o fenômeno da globalização, merecendo desde já a constatação de que se trata de um processo histórico com traços iniciais esboçados desde o século $\mathrm{XV}$, embora seu maior desenvolvimento se mostre mais evidente a partir da segunda metade do século XX, período em que seus reflexos foram mais sensivelmente sentidos no contexto mundial.

É, então, a partir do estabelecimento da premissa inicial de uma estreita relação entre a técnica e a globalização que se buscará compreender melhor a manifestação, as consequências e a dinâmica da criminalidade transnacional ${ }^{6}$ no mundo contemporâneo. Para tanto, parte-se da ideia de que essa relação é cíclica e dinâmica, pois tanto a técnica influencia o incremento da globalização, como a globalização é um fator catalisador da técnica.

Importante destacar que a globalização, superando o reducionismo da sua caracterização como mera "eliminação das fronteiras" ou de "aldeia global"7, de fato é um

ao cabo, coincide com a própria história”. (COSTA, José de Faria. Direito Penal e Globalização: reflexões não locais e pouco globais. Coimbra: Coimbra Editora, 2010. p. 9).

${ }^{4}$ SANTOS, Milton. Por uma outra globalização: do pensamento único à consciência universal. Rio de Janeiro: Record, 2010. p. 63.

5 Para melhor aprofundamento: BECK, Ulrich. Sociedade de risco. Rumo a uma outra modernidade. São Paulo: Editora 34, 2011.

${ }^{6}$ O termo transnacional é associado a Philip Jessup, apontado como o primeiro doutrinador a utilizá-lo relacionando-o com o que ele define ser "as normas que regulam atos ou fatos que transcendem fronteiras nacionais". Para ele, o termo é mais abrangente do que direito internacional, normalmente focado nas relações - internacionais - entre os Estados, de maneira que o direito transnacional abrangeria também os indivíduos, as empresas, os Estados, as organizações de Estado, ou outros grupos. (JESSUP, Philip C. Direito transnacional. Rio de Janeiro: Editora Fundo de Cultura S/A, 1965. p. 12-13).

${ }^{7}$ Termo associado a McLuhan, merecendo destacar a crítica do geógrafo Milton Santos que compara a "aldeia" a uma fábula, pois nos faz crer - fantasiosamente - que dentro da "aldeia" a difusão, em tempo real, das notícias de fato informa as pessoas, e que o encurtamento das distâncias permite às pessoas viajarem pelo mundo como um passe de mágica. Ainda, afirma que a uniformidade pretendida pela "aldeia" está a serviço dos atores hegemônicos mundiais, mas de fato o mundo tem se tornado cada vez menos unido e distante da noção de "cidadania universal", como hoje fica bastante evidente nos inúmeros problemas decorrentes dos fluxos migratórios, inclusive com tratamento penal (crimigração) de um fenômeno bastante complexo. 
fenômeno de reflexos difusos, sem padrão fixo e predeterminado de desenvolvimento, comportando-se paradoxalmente: integrativo e fragmentário, incluindo e excluindo, convergindo e divergindo ${ }^{8}$. Além do mais, não se pode ignorar as diferentes percepções a partir de inúmeras causas, pois "diferentes conjuntos de relações sociais dão origem a diferentes fenômenos de globalização", o que implicaria na utilização do termo globalizações. Porém, considerando o emprego comum do termo no singular, nesse trabalho serão tratados como sinônimos, ou ocasionalmente, acrescentado do termo fenômeno para se referir à globalização na sua devida complexidade.

Acerca da construção teórica sobre a globalização e desde uma perspectiva de aparente neutralidade ${ }^{10}$, Roland Robertson, sociólogo europeu, sistematiza a globalização como um processo histórico com raízes no século $\mathrm{XV}$, associando-a com a expansão marítima europeia e subdividindo o processo em fases distintas, a saber: (a) fase embrionária; (b) fase incipiente; (c) fase de decolagem; (d) fase da luta por hegemonia; e (e) fase da incerteza ${ }^{11}$. Não é difícil concordar com a abordagem feita, mas evidentemente carece de outros aspectos úteis para a compreensão do fenômeno na sua adequada amplitude, já que os reflexos são evidentemente mais difusos.

A abordagem feita por Giddens explica o fenômeno da globalização a partir da visão de dois grupos essencialmente antagônicos: os céticos e os radicais. Para ele, os céticos entendem que a globalização não influenciou qualquer mudança no mundo, sendo que os fenômenos sentidos atualmente são meras consequências naturais do que já havia sido anteriormente estabelecido nas dinâmicas sociais e "evolução" da sociedade ${ }^{12}$. Por outro lado, os radicais defendem que a globalização interfere em todos os aspectos da vida humana e que seria até mesmo responsável pelo desaparecimento do Estado-nação, das

(SANTOS, Milton. Por uma outra globalização: do pensamento único à consciência universal. Rio de Janeiro: Record, 2010. p. 18-19).

${ }^{8}$ HELD, David; McGREW, Anthony. Prós e contras da Globalização. Rio de Janeiro: Jorge Hazar Ed., 2001. p. 21.

${ }^{9}$ SOUSA SANTOS, Boaventura (org.). A Globalização e as Ciências sociais. São Paulo: Cortez, 2011. p. 55.

${ }^{10}$ Embora ainda bastante presente na contemporaneidade, diversos estudos já demonstram a superação do paradigma clássico cientificista de separação (neutralidade) entre sujeito e objeto de pesquisa. Entre tantos: Edgar Morin, llya Prigogine, Boaventura de Sousa Santos, entre outros.

${ }^{11}$ ROBERTSON, Roland. Globalização: teoria social e cultural global. Petrópolis: Editora Vozes, 2000. p. 88.

${ }^{12}$ GIDDENS, Anthony. Mundo em descontrole: o que a globalização está fazendo de nós. Rio de Janeiro: Record, 2011. p. 18-21. 
Revista Eletrônica de Direito Processual - REDP.

Rio de Janeiro. Ano 12. Volume 19. Número 1. Janeiro a Abril de 2018

Periódico Quadrimestral da Pós-Graduação Stricto Sensu em Direito Processual da UERJ

Patrono: José Carlos Barbosa Moreira (in mem.). ISSN 1982-7636. pp. 35-61

www.redp.uerj.br

fronteiras, da soberania, existindo tais conceitos (Estado, fronteira, etc.) apenas como ficção ou fantoche dos reais donos do $\operatorname{poder}^{13}$.

Ocorre que a visão do fenômeno da globalização abordada por ambos os grupos citados por Giddens é um tanto estrábica, pois notadamente voltada apenas para os reflexos econômicos. Desta feita, a compreensão da globalização como um fenômeno mundial, só pode ser construída a partir de uma visão histórica e comparativa ${ }^{14}$, que requer, necessariamente, um tratamento transdisciplinar e compromissado com a sua complexidade $^{15}$.

De fato, embora seus reflexos sejam mais sensivelmente visualizados no sistema econômico, a globalização é um fenômeno essencialmente multifacetário (político, cultural, econômico, social, jurídico, etc.) de intensificação das relações sociais em escala mundial $^{16}$. Isso porque as manifestações da globalização "ligam localidades distantes de tal maneira que acontecimentos locais são modelados por eventos ocorrendo a muitas milhas de distância e vice-versa"17, revelando processos eminentemente dialéticos, já que a transformação local é tanto um componente da globalização como extensão das conexões sociais, fazendo com que o que ocorra localmente tende a ser bastante influenciado por fatores globais ao mesmo tempo em que - paradoxalmente - os acontecimentos locais alcancem repercussão mundial $^{18}$, construindo a ideia de rede global de integração ${ }^{19}$.

Essa constatação fica evidente no cotidiano quando se observa diversos acontecimentos em outros países influenciando diretamente outros Estados. Como exemplo, recentemente há uma crise internacional envolvendo EUA e Coréia do Norte, que atinge interesses da China e influência na cotação do dólar no Brasil, demonstrando a rede global de interações vivenciadas na contemporaneidade.

\footnotetext{
${ }^{13}$ GIDDENS, Anthony. Mundo em descontrole: o que a globalização está fazendo de nós. Rio de Janeiro: Record, 2011. p. 18-21.

${ }^{14}$ ROBERTSON, Roland. Globalização: teoria social e cultural global. Petrópolis: Editora Vozes, 2000. p. 79.

${ }^{15}$ MORIN, Edgar. Ciência com consciência. Rio de Janeiro: Bertrand Brasil, 2010. p. 177.

${ }^{16}$ GIDDENS, Anthony. As consequências da modernidade. São Paulo: Editora Unesp, 1991. p. 76.

${ }^{17}$ GIDDENS, Anthony. As consequências da modernidade. São Paulo: Editora Unesp, 1991. p. 76.

18 Interessante mencionar a frase do sociólogo Daniel Bell quando afirma que "a nação se torna não só pequena demais para resolver os grandes problemas, como também grande demais para resolver os pequenos". (GIDDENS, Anthony. Mundo em descontrole: o que a globalização está fazendo de nós. Rio de Janeiro: Record, 2011. p. 23).

${ }^{19}$ SLAUGHTER, Anne-Marie. The New World Order. New Jersey: Princeton University Press, 2004. p. 15.
} 
Revista Eletrônica de Direito Processual - REDP.

Rio de Janeiro. Ano 12. Volume 19. Número 1. Janeiro a Abril de 2018

Periódico Quadrimestral da Pós-Graduação Stricto Sensu em Direito Processual da UERJ

Patrono: José Carlos Barbosa Moreira (in mem.). ISSN 1982-7636. pp. 35-61 www.redp.uerj.br

Assim, fica estabelecida a premissa de que a globalização é um fenômeno complexo/transdisciplinar ${ }^{20}$ cuja característica mais notável é a compressão do espaçotempo, formando redes globais de relações sociais, com íntima afinidade com o desenvolvimento da técnica. Essa constatação é a base conceitual necessária para a análise mais apropriada da criminalidade - transnacional - contemporânea, pois constitui um dos pilares da dinâmica do desenvolvimento das atividades criminosas, também funcionando em rede global.

Concretamente, o panorama contemporâneo, marcado pelas características acima expostas, revela também uma considerável alteração na manifestação do crime transnacional. Para isso, vale citar o exemplo trazido por Jeffrey Robinson ${ }^{21}$ como forma de ilustrar e problematizar a dinâmica e a dimensão do fenômeno da globalização em relação ao crime transnacional e as diversas questões suscitadas na atualidade.

Trata-se de um fato ocorrido com um cidadão da cidade de Vancouver (Canadá), que nunca havia saído da sua cidade natal e, como de praxe, em certo dia entrou em uma loja de bebidas para comprar vinhos para o jantar. $\mathrm{O}$ balconista, membro de uma quadrilha vietnamita, atendeu o senhor e fez várias sugestões diante das inúmeras opções de bebidas à disposição. Finalizada a escolha, a compra das bebidas totalizou 78,00 dólares, pagos através do cartão de crédito ${ }^{22}$.

Ocorre que, no momento em que o senhor canadense forneceu o cartão de crédito, este foi passado também em uma máquina própria para a clonagem de cartões. Sem desconfiar de nada, antes mesmo de terminar o jantar com a sua esposa, o número do cartão de crédito e todas as informações codificadas da tarjeta do cartão magnético já haviam sido enviadas para Hong Kong (China) via e-mail ${ }^{23}$.

Nesse mesmo local, centenas de outros e-mails eram recebidos com informações de vítimas localizadas, principalmente, nos Estados Unidos e Canadá. Da China, todas essas informações, depois de filtradas, eram enviadas para a Malásia, onde novos cartões eram confeccionados com base nas informações clonadas ${ }^{24}$.

\footnotetext{
${ }^{20}$ Para Habermas, "os processos de globalização - que não são apenas de natureza econômica - acostumamnos mais e mais a uma outra perspectiva, a partir da qual fica cada vez mais evidente a estreiteza dos teatros sociais, o caráter público dos riscos e o enredamento dos destinos coletivos." (HABERMAS, Jürgen. A constelação pós-nacional. São Paulo: Littera Mundi, 2001. p. 72).

${ }^{21}$ ROBINSON, Jeffrey. A Globalização do crime. Rio de Janeiro: Ediouro, 2001. p. 20-23.

${ }^{22}$ ROBINSON, Jeffrey. A Globalização do crime. Rio de Janeiro: Ediouro, 2001. p. 22.

${ }^{23}$ ROBINSON, Jeffrey. A Globalização do crime. Rio de Janeiro: Ediouro, 2001. p. 22.

${ }^{24}$ ROBINSON, Jeffrey. A Globalização do crime. Rio de Janeiro: Ediouro, 2001. p. 22.
} 
Em 24 horas, 199 novos cartões eram entregues no aeroporto de Kuala Lumpur

(Malásia), dissimulados no interior de caixas de cigarros, para outros indivíduos com destino a Milão (Itália) com escala em Praga (República Tcheca). Lá, 25 cartões, entre eles o do cidadão canadense, foram entregues a um russo que seguia para Londres (Inglaterra) $^{25}$.

Em menos de 3 dias, o cartão de crédito em nome do cidadão canadense estava sendo utilizado na loja Harrods, em Londres, para comprar artigos de luxo. Após as compras, o senhor russo retornou à Praga (República Tcheca), onde os produtos comprados foram então enviados para Moscou (Rússia) por meio de caminhões, e em uma semana estavam sendo vendidos em lojas no Kremlin ${ }^{26}$.

Em suma, os membros de uma quadrilha vietnamita eram pagos por uma Tríade chinesa para duplicar os cartões dos clientes, vendendo-os para um membro da Camorra, responsável pelo repasse a algum grupo criminoso russo. Conclusão: a essa altura, não é mais possível ter certeza sobre qual jurisdição o crime - ou crimes - em questão estariam submetidos, quais os atores criminosos realmente se envolveram no processo, etc. ${ }^{27}$.

Esse exemplo ilustra simbolicamente a complexa dinâmica do crime transnacional e a árdua tarefa de conseguir traçar os parâmetros da responsabilidade criminal $^{28} \mathrm{em}$ relação a cada agente criminoso, Estado envolvido, os limites de cada jurisdição, entre outros, principalmente tendo em vista a grande capacidade de rápida mobilidade e do uso de meios tecnológicos altamente modernos na prática desse tipo de criminalidade.

\footnotetext{
${ }^{25}$ ROBINSON, Jeffrey. A Globalização do crime. Rio de Janeiro: Ediouro, 2001. p. 23.

${ }^{26}$ ROBINSON, Jeffrey. A Globalização do crime. Rio de Janeiro: Ediouro, 2001. p. 23.

${ }^{27}$ ROBINSON, Jeffrey. A Globalização do crime. Rio de Janeiro: Ediouro, 2001. p. 23.

${ }^{28}$ Ao tratar do princípio da territorialidade da lei penal, Figueiredo Dias se manifesta no seguinte sentido: "A generalidade dos sistemas legislativos penais dos nossos dias assume como principio basilar de aplicação da sua lei penal no espaço o princípio da territorialidade, não o da nacionalidade. E é esta a posição tradicional do direito penal português. Pode afirmar-se que nesta preferencia convergem razões de índole interna e razões de índole externa ou, se quiser ser-se mais preciso, razões próprias de direito penal e de politica criminal, de um lado, razões de direito internacional e de politica estadual, do outro. Começando por estas últimas - as razões jurídico-internacionais e de politica estadual -, deve conceder-se facilmente que a assunção do principio da territorialidade como base do sistema de aplicação da lei penal no espaço é a via que facilitará em maior medida a harmonia internacional, o respeito pela não ingerência em assuntos de um Estado estrangeiro. Se a aplicação espacial da lei penal nacional é rigorosamente demarcada por sobre as fronteiras de cada Estado, e se a generalidade dos Estados aceita este principio, está então descoberto o melhor caminho para que não se gerem conflitos internacionais - positivos ou negativos - de competência interestadual. Se a generalidade dos Estados aceitar o principio-base da territorialidade, um Estado que aceite o principio pessoal ver-se-á a cada passo confrontado com aqueles conflitos e com a acusação respectiva de ingerência. Num momento, como o presente, em que a política criminal tende a universalizar-se, a consagração da nacionalidade como principio básico de aplicação no espaço não poderia deixar, por isso, de ser considerada como internacionalmente disfuncional." (FIGUEIREDO DIAS, Jorge de. Direito Penal: parte geral. Coimbra: Coimbra editora, 2012. p. 209-210).
} 
Revista Eletrônica de Direito Processual - REDP.

Rio de Janeiro. Ano 12. Volume 19. Número 1. Janeiro a Abril de 2018

Periódico Quadrimestral da Pós-Graduação Stricto Sensu em Direito Processual da UERJ

Patrono: José Carlos Barbosa Moreira (in mem.). ISSN 1982-7636. pp. 35-61 www.redp.uerj.br

Fica bastante difícil também determinar dados seguros para enfrentamento dessa espécie de crime, também pela dificuldade de realmente estabelecer toda a cadeia do caminho do crime. Vale destacar que o exemplo citado se refere a um grande esquema de crime organizado transnacional, mas não se pode perder de vistas os incontáveis crimes que ocorrem ao longo das fronteiras secas dos países e cuja determinação de competência e interação entre os agentes sempre é mais dificultosa.

No plano internacional, a preocupação com esse novo panorama levou à confecção da Convenção das Nações Unidas contra o Crime Organizado Transnacional $(\mathrm{UNTOC})^{29}$, também conhecida como Convenção de Palermo (2000), com propósito de "promover a cooperação para prevenir e combater mais eficazmente o crime organizado transnacional" convencidos de que a Convenção constitui uma ferramenta efetiva e o panorama normativo necessário para cooperação internacional no enfrentamento da lavagem de dinheiro, corrupção, tráficos de armas, drogas, etc., e também o crime organizado transnacional (tradução do autor) ${ }^{30}$.

Ainda no plano internacional, a preocupação das diferentes nações foi responsável pela criação de diversos instrumentos normativos envolvendo essa temática, ora voltados para contexto regional, ora internacional, mas sempre demonstrando preocupação com o enfrentamento da dinâmica transnacional da criminalidade a partir da cooperação entre os Estados. Afinal, as respostas para compreensão e enfrentamento desse fenômeno só poderia surgir a partir do diálogo e intercâmbio entre os órgãos envolvidos com a persecução penal também funcionando em rede.

\footnotetext{
${ }^{29}$ A Convenção de Palermo, foi ratificada pelo Brasil através do Decreto ${ }^{\circ}$ 5.015/2004, sendo que o então Secretário Geral da ONU, Kofi A. Annan, assim se manifesta no prefácio da Convenção: “A comunidade internacional demonstrou o anseio politico de resolver os desafios globais com uma resposta global. Se o crime atravessa as fronteiras, assim deve também ocorrer com a aplicação da lei. [...] Se os inimigos do progresso e dos direitos humanos procuram explorar as facilidades e oportunidades fornecidas pela globalização para seus propósitos, então temos que explorar esses mesmos fatores para a defesa dos direitos humanos e derrotar as forças ligadas ao crime, corrupção e trafico de seres humanos. [...] Os grupos criminais não desperdiçaram tempo para se agregarem à economia globalizada e a tecnologia sofisticada que a ela acompanha. Mas os nossos esforços para combatê-los permaneceram até o momento fragmentado e as 'armas' obsoletas. A Convenção nos proporciona uma nova ferramenta para situar o flagelo do crime como um problema global." (tradução do autor). (Disponível em: <http://www.unodc.org/documents/treaties/UNTOC/Publications/TOC\%20Convention/TOCebook-e.pdf> Acesso em 03 abr. 2014).

Disponível em: <http://www.unodc.org/documents/treaties/UNTOC/Publications/TOC\%20Convention/TOCebook-e.pdf> Acesso em 03 abr. 2014
} 
Ocorre que o problema se instala ao buscar o adequado equilíbrio entre uma efetiva/célere ${ }^{31}$ persecução penal e as garantias do indivíduo submetido a ela. Se essa já é uma das chagas do processo penal "local", quando elevado ao plano transnacional revela maior preocupação, já que normalmente também envolve discursos midiáticos de "combate" ou "guerra",32, o que por si só acaba desnaturalizando a própria essência do processo penal rumo a mera busca por punição, muitas vezes a qualquer custo.

Para tanto, é necessário identificar as balizas conceituais da criminalidade transnacional com intuito de melhor compreender as suas manifestações e possíveis ferramentas e limites na persecução penal. E é exatamente nesse ponto que situa a importante reflexão conceitual da globalização e a dinâmica do crime transnacional, pois, ao contrário do que comumente tem se difundido sobre o "fim das fronteiras", a bem da verdade o crime transnacional justamente se vale da rigidez das fronteiras (como limite da jurisdição nacional) para melhor otimizar suas atividades.

De fato, atualmente as fronteiras e a soberania dos Estados estão ficando cada vez mais rígidas (embora permeáveis), bastando constatar o reforço das fronteiras em relação a crise migratória no espaço da União Europeia, mas também nos EUA e, na América Latina, em relação ao tráfico de drogas, contrabando, etc. Desta forma, é possível afirmar que a fronteira constitui um marco delimitador ainda muito importante de atuação do Estado na persecução penal, razão pela qual é relevante também definir os contornos conceituais do crime transnacional.

\section{O caráter transnacional e internacional dos crimes: aproximações e afastamentos} teóricos.

Há de maneira geral uma confusão no tratamento da matéria em razão de uma possível aproximação dos termos internacional e transnacional. Vale ressaltar que não se trata de preciosismo terminológico, mas verdadeiramente categorias normativas e

\footnotetext{
${ }^{31}$ Vale a reflexão de Faria Costa, quando afirma que "é claro que este nosso modelo pode ser muito, mas muito mais ágil e célere. $\mathrm{E}$ a fórmula todos a conhecem. Basta diminuir drasticamente as garantias do suspeito, do arguido, do acusado e do condenado para que tudo seja mais breve. Mas é isso que se quer? É isso que quer uma verdadeira e real comunidade democrática? É isso o que corresponde a uma saudável cultura de defesa e promoção dos direitos fundamentais?" (COSTA, José de Faria. Direito Penal e Globalização: reflexões não locais e pouco globais. Coimbra: Coimbra Editora, 2010. p. 14).

${ }^{32}$ HASSEMER, Weinfried. Perspectivas del Derecho penal futuro. p. 37-41. Revista Penal, v.1, jan., HuelvaSalamanca-Castilla-La Mancha, 1998. p. 38.
} 
Revista Eletrônica de Direito Processual - REDP.

Rio de Janeiro. Ano 12. Volume 19. Número 1. Janeiro a Abril de 2018

Periódico Quadrimestral da Pós-Graduação Stricto Sensu em Direito Processual da UERJ

Patrono: José Carlos Barbosa Moreira (in mem.). ISSN 1982-7636. pp. 35-61

www.redp.uerj.br

conceituais bastante diferentes, refletindo diretamente no tratamento penal e processual de

cada uma das manifestações criminosas.

Em primeiro lugar, o termo crime internacional se refere a crimes graves "que afetam a comunidade internacional no seu conjunto" ${ }^{33}$, conforme está delimitado de forma bem clara no Estatuto de Roma ${ }^{34}$, que além de criar o Tribunal Penal Internacional (TPI), definiu os crimes submetidos à sua competência ${ }^{35}$ (art. $\left.5^{\circ}, 1\right)$, e que são: o genocídio, os crimes contra a humanidade, os crimes de guerra e os crimes de agressão ${ }^{36}$. Tanto o Tribunal Penal Internacional, quanto os crimes submetidos a sua competência (os crimes internacionais) nascem de uma necessidade bastante específica e dentro do contexto pósSegunda Guerra Mundial (Tribunal Militar de Nuremberg, 1947) de persecução penal de

\footnotetext{
${ }^{33}$ Art. 5 $5^{\circ}$, do Estatuto de Roma (Decreto n ${ }^{\circ} 4.388$, de 25 de setembro de 2002).

${ }^{34}$ O Estatuto de Roma, criado em 1998, foi ratificado pelo Brasil por meio do Decreto 4.388/2002 e tem as seguintes considerações em seu preâmbulo: "Os Estados Partes no presente Estatuto. Conscientes de que todos os povos estão unidos por laços comuns e de que suas culturas foram construídas sobre uma herança que partilham, e preocupados com o fato deste delicado mosaico poder vir a quebrar-se a qualquer instante; Tendo presente que, no decurso deste século, milhões de crianças, homens e mulheres têm sido vítimas de atrocidades inimagináveis que chocam profundamente a consciência da humanidade; Reconhecendo que crimes de uma tal gravidade constituem uma ameaça à paz, à segurança e ao bem-estar da humanidade; Afirmando que os crimes de maior gravidade, que afetam a comunidade internacional no seu conjunto, não devem ficar impunes e que a sua repressão deve ser efetivamente assegurada através da adoção de medidas em nível nacional e do reforço da cooperação internacional; Decididos a por fim à impunidade dos autores desses crimes e a contribuir assim para a prevenção de tais crimes; Relembrando que é dever de cada Estado exercer a respectiva jurisdição penal sobre os responsáveis por crimes internacionais; Reafirmando os Objetivos e Princípios consignados na Carta das Nações Unidas e, em particular, que todos os Estados se devem abster de recorrer à ameaça ou ao uso da força, contra a integridade territorial ou a independência política de qualquer Estado, ou de atuar por qualquer outra forma incompatível com os Objetivos das Nações Unidas; Salientando, a este propósito, que nada no presente Estatuto deverá ser entendido como autorizando qualquer Estado Parte a intervir em um conflito armado ou nos assuntos internos de qualquer Estado; Determinados em perseguir este objetivo e no interesse das gerações presentes e vindouras, a criar um Tribunal Penal Internacional com caráter permanente e independente, no âmbito do sistema das Nações Unidas, e com jurisdição sobre os crimes de maior gravidade que afetem a comunidade internacional no seu conjunto; Sublinhando que o Tribunal Penal Internacional, criado pelo presente Estatuto, será complementar às jurisdições penais nacionais; Decididos a garantir o respeito duradouro pela efetivação da justiça internacional;” (grifos do autor). (Disponível em <http://www.planalto.gov.br/ccivil 03/decreto/2002/D4388.htm> Acesso em 24 ago. 2014).

35 A jurisdição criminal do TPI é permanente, automática (não precisa de aderência), independente e complementar (não exclui a jurisdição nacional), atuando quando não houver incapacidade ou falta de vontade em investigar e punir os crimes da sua competência. (GIACOMOLLI, Nereu. $O$ devido processo penal: abordagem conforme a Constituição Federal e o Pacto de São José da Costa Rica. São Paulo: Atlas, 2014. p. 5).

${ }^{36}$ Embora esses sejam os únicos crimes taxativamente estabelecidos no Estatuto de Roma, tem-se aceito na contemporaneidade também como crimes internacionais o Terrorismo e atos individuais de Tortura. Por vezes enquadradas nas categorias previstas no Estatuto, há uma tutela internacional dessas espécies delituosas em outras Convenções (por exemplo, UN Conv. Against Torture, 1984) o que poderia autorizar a persecução internacional de tais crimes. (EVANS, Malcolm D. International Law. United Kingdom: Oxford University Press, 2014. p. 753).
} 
um fenômeno criminoso complexo e envolto em repercussão internacional ${ }^{37}$ de violação de direitos humanos.

Aliás, o próprio Tribunal de Nuremberg estabeleceu standard de responsabilização criminal de indivíduos no sentido de possuírem "deveres internacionais que transcendem as obrigações nacionais de obediência imposta por um único Estado (...) crimes contra o direito internacional ${ }^{38}$ são cometidos por pessoas, não por uma entidade abstrata, e somente com a punição dos indivíduos que cometeram tais crimes as normas de direito internacional serão aplicadas" (tradução do autor) ${ }^{39}$. Dessa forma, estabeleceu duas premissas importantes no contexto global e que até hoje são aplicadas: a criminalização das agressões contra uma coletividade e a responsabilização pessoal dos agentes, mesmo que busquem justificar seus atos como mero cumprimento de ordens superiores ${ }^{40}$.

De forma mais específica, a criminalidade internacional está relacionada com a prática de atos que em sua essência consistem em (i) violações das regras do direito consuetudinário internacional ou tratados internacionais que protegem valores considerados importantes no âmbito da comunidade internacional, onde (ii) haja um interesse universal da repressão desses crimes sob o ordenamento jurídico internacional que permite a qualquer Estado perseguir e punir o(s) criminoso(s), independentemente de qualquer vinculação territorial ou de nacionalidade entre o autor e a vítima, e que caso (iii) o perpetuador tenha agido oficialmente (de direito ou de fato como um oficial de um Estado) lhe seja proibido alegar a imunidade civil ou criminal da jurisdição dos estados estrangeiros ${ }^{41}$.

Dessa forma, é plenamente possível que a perpetuação material (ação e resultado) de um crime internacional ocorra inteiramente apenas dentro de um único país, portanto, sem a necessidade de transposição de qualquer espaço limítrofe entre estados nacionais. Assim, a persecução penal de crimes internacionais se dá principalmente pela repercussão internacional (gravidade, natureza, etc.), independentemente se a ação material envolve outros países.

\footnotetext{
${ }^{37}$ CANNIZZARO, Enzo. Diritto Internazionale. Torino: G. Giappichell, 2014. p. 442.

${ }^{38}$ No idioma original é crimes against international law.

${ }^{39}$ EVANS, Malcolm D. International Law. United Kingdom: Oxford University Press, 2014. p. 752.

${ }^{40}$ CASSESSE, Antonio. Il sogno dei diritti umani. Milano: Giangiacomo Feltrinelli Editore, 2008. p. 126.

${ }^{41}$ CASSESSE, Antonio. International Law. New York: Oxford University Press, 2005. p. 436.
} 
A esse respeito, vale mencionar que antes do estabelecimento do Tribunal Penal Internacional $(1998)^{42}$, de caráter permanente, diversos casos de crimes internacionais foram apurados mediante tribunais ad-hoc como Ex-Iugoslávia (1993) e Ruanda (1994), e que de fato contribuíram para a "luta contra a impunidade de criminosos de guerra e de responsáveis por atos de genocídio e crimes contra a humanidade, superando assim uma das carências do Direito Internacional clássico" ${ }^{\text {. }}$.

Por outro lado, os crimes transnacionais envolvem a prática de ilícitos com a violação de ordenamentos jurídicos nacionais e, necessariamente, interferindo em outro ou outros países ${ }^{44}$. Dessa forma, a ação criminosa envolverá mais de um país em alguma das fases do iter criminis e a tipificação da conduta está, via de regra, nos ordenamentos jurídicos internos dos países, e apenas excepcionalmente em tratados internacionais, depois de serem ratificados internamente em cada país.

No plano internacional, a principal baliza normativa do conceito e características do crime transnacional é a Convenção de Palermo, que em seu artigo $3^{\circ}, 2$ o descreve, alternativamente, como aquele que (i) for cometido em mais de um Estado; (ii) for cometido em um só Estado, mas com parte da sua composição (preparação, planejamento, direção e controle) em outro; (iii) cometido em um Estado, mas com participação de grupo criminoso que pratique atividades criminosas em mais de um Estado; ou, por fim, (iv) for cometido em um só Estado, mas com efeitos substanciais em outro ${ }^{45}$.

Para o UNODC - United Nations Office on Drugs and Crime $^{46}-$, o crime organizado transnacional não é um conceito estático e constantemente se adapta ao mercado, criando novas formas de agir e cujo "palco de operações" transcende barreiras culturais, sociais, linguísticas e geográficas. O UNODC ainda aponta como as principais -

\footnotetext{
${ }^{42}$ Entrando em vigor no ano de 2002.

43 TRINDADE, Antônio A. Cançado. Os Tribunais Internacionais Contemporâneos. Brasília: FUNAG, 2013. p. 31-33.

44 DAVIN, João. A Criminalidade organizada transnacional: a cooperação judiciária e policial na UE. Coimbra: Almedina, 2007. p. 109.

${ }^{45}$ A opinião da UNODC (United Nations Office on Drugs and Crime) é no sentido de que essa conceituação abrange de forma bem ampla a grande maioria dos crimes econômicos e as atividades criminosas graves com implicação internacional. Também dá conta da complexidade global desses crimes que exigem a cooperação na maior escala possível para resolver as preocupações em comum dos Estados envolvidos. (Disponível em <http://www.unodc.org/unodc/en/organized-crime/index.html\#what_organized_crime> Acesso em 03 abr. 2014).

46 O UNODC “é o líder global no combate contra as drogas e crimes internacionais. Estabelecido em 1997 pela mescla entre o Programa das Nações Unidas para Controle das Drogas e o Centro de prevenção de crimes internacionais, o UNODC opera em todas as regiões do mundo através de uma extensa rede de oficias de campo." (tradução do autor). (Disponível em <http://www.unodc.org/unodc/en/about-
} unodc/index.html?ref=menutop $>$ Acesso em 03 abr. 2014). 

tráfico de seres humanos ${ }^{48}$; (iii) contrabando de imigrantes ${ }^{49}$; (iv) tráfico ilícito de armas ${ }^{50}$; (v) tráfico de recursos naturais ${ }^{51}$; (vi) tráfico ilícito de animais silvestres ${ }^{52}$; (vii) comércio ilegal de medicamentos falsificados; e (viii) cybercrime $^{53} ;{ }^{54}$

De maneira geral, a criminalidade transnacional se caracteriza, então, pela sua internacionalização, sofisticação, ampla troca de informações relevantes, identificação de oportunidades criminais no mercado global e cuidadosa estruturação interna ${ }^{55}$. Tudo isso, visando primordialmente à maximização dos rendimentos ilicitamente obtidos ${ }^{56} \mathrm{e}$ à minimização dos riscos quanto à perda e confisco de bens ${ }^{57}$.

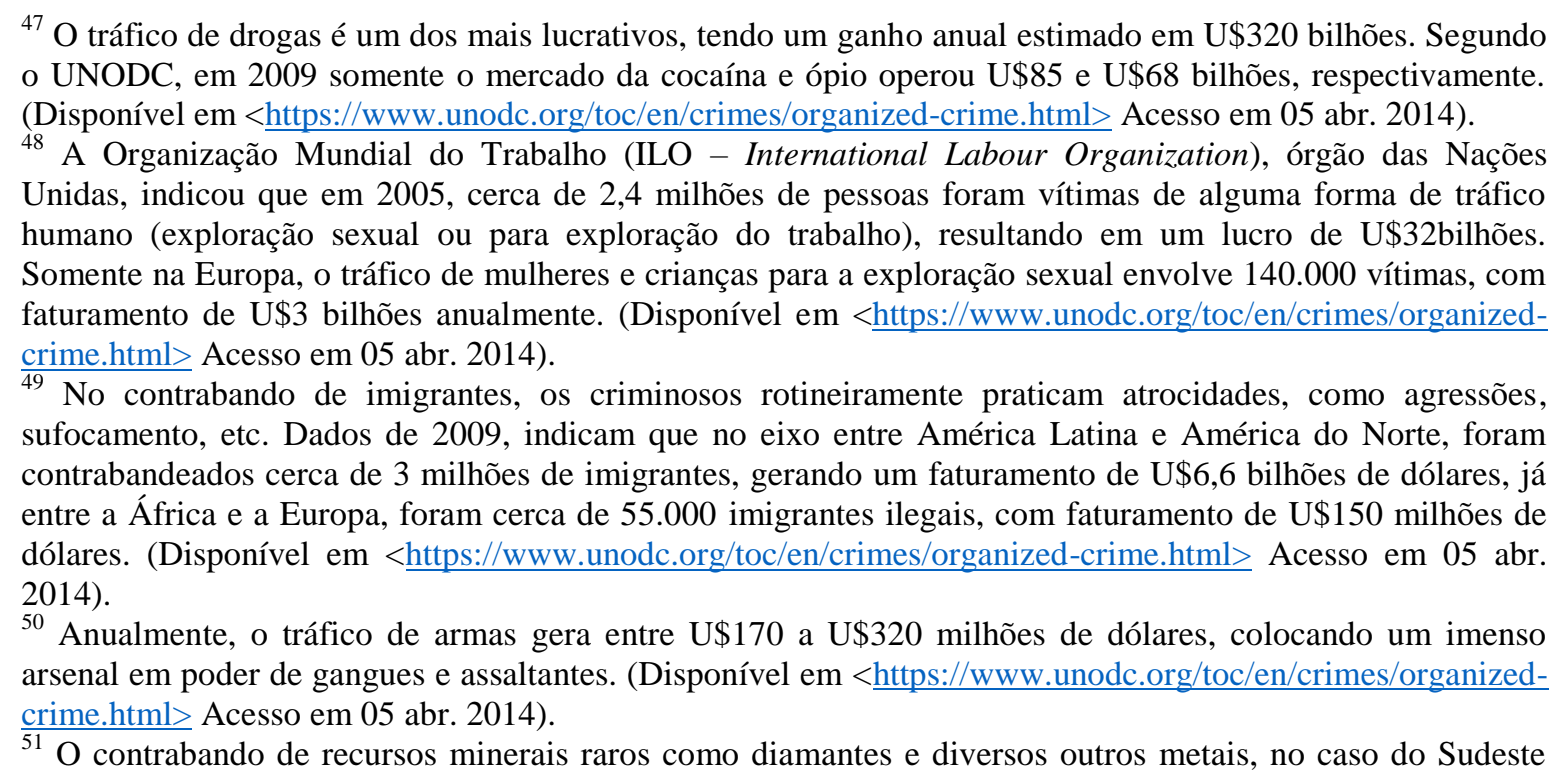
Asiático gera anualmente uma renda de U\$3,5 bilhões de dólares. (Disponível em: $<$ https://www.unodc.org/toc/en/crimes/organized-crime.html> Acesso em 05 abr. 2014).

${ }^{52}$ Sem dúvida, o tráfico de animais silvestres é uma atividade bastante lucrativa no mundo do crime transnacional e, conforme apontam os dados divulgados pela UNODC, o tráfico de marfim, corno de rinoceronte e partes de tigres da África e Sudeste Asiático produz um lucro de U\$75 milhões de dólares a cada ano, além de ameaça às espécies em questão. Conforme a WWF, os traficantes movimentam aproximadamente 100 milhões de toneladas de peixes, 1.5 milhão de aves vivas e 440.000 toneladas de plantas medicinais a cada ano. (Disponível em: <https://www.unodc.org/toc/en/crimes/organizedcrime.html> Acesso em 05 abr. 2014).

${ }^{53}$ Trata-se de um campo relativamente novo e com ampla aplicação em diversos setores, mas atualmente é um dos negócios mais lucrativos, gerando cerca de U\$1 bilhão a cada ano. Os criminosos tem aumentado cada vez mais o furto de dados privados, acesso a informações de contas bancárias e pagamentos fraudulentos através de cartões de crédito clonados. (Disponível em: $\langle$ https://www.unodc.org/toc/en/crimes/organized-crime.html> Acesso em 05 abr. 2014).

${ }^{54}$ Dados estatísticos retirados do endereço eletrônico do UNODC. (Disponível em: $\langle$ https://www.unodc.org/toc/en/crimes/organized-crime.html> Acesso em 05 abr. 2014).

55 DAVIN, João. A Criminalidade organizada transnacional: a cooperação judiciária e policial na UE. Coimbra: Almedina, 2007. p. 110.

${ }^{56}$ Segundo dados divulgados pela UNODC (United Nations Office on Drugs and Crime), em 2009 foi estimado que o crime organizado transnacional gerou a quantia de U\$870 bilhões, o que equivale a 
Revista Eletrônica de Direito Processual - REDP.

Rio de Janeiro. Ano 12. Volume 19. Número 1. Janeiro a Abril de 2018

Periódico Quadrimestral da Pós-Graduação Stricto Sensu em Direito Processual da UERJ

Patrono: José Carlos Barbosa Moreira (in mem.). ISSN 1982-7636. pp. 35-61 www.redp.uerj.br

Para atingir tais objetivos, segundo Davin, a criminalidade transnacional tem assento basicamente em quatro pilares: (i) financiamento do tráfico de drogas, armas e seres humanos; (ii) utilização de novas tecnologias de comunicação e informação; (iii) rentabilização ou potencialização dos ganhos por meio de lavagem de dinheiro e investimento em atividades - aparentemente - lícitas, bem como tráfico de influência e corrupção; (iv) "branqueamento de imagem", relacionada com a credibilidade socioeconômica e respeitabilidade, através da infiltração nos mais elevados estratos sociais $^{58}$.

Além das características descritas, um importante fator relacionado ao poderio econômico do crime transnacional é o seu alto nível qualitativo de defesa técnica em possíveis processos criminais, decorrentes, consequentemente, do elevado poder econômico que detêm. Isso reflete na obtenção de informação técnica privilegiada apta a utilizar, convenientemente, das brechas dos diversos ordenamentos jurídicos dos diferentes Estados onde há atuação criminosa, valendo-se, principalmente, da dificuldade de investigação e do recolhimento de provas ${ }^{59}$.

Por sua vez, Silva Sánchez, no que denomina de criminalidade global, afirma que em seu cerne estrutural existem duas características principais. A primeira se refere genericamente a uma criminalidade essencialmente organizada ou hierarquicamente estruturada, que busca dissociar a execução material do delito e a responsabilidade ou o controle das ações, o que implica na possibilidade do resultado lesivo ser separado no espaço e tempo ${ }^{60}$.

A segunda característica, analisada do ponto de vista material, revela que a criminalidade globalizada é uma criminalidade de sujeitos poderosos (crimes of the powerful), marcada pela magnitude dos seus efeitos, principalmente econômicos, mas também políticos e sociais. Notavelmente, tem alta capacidade de desestabilização dos

aproximadamente 7 por cento da mercadoria exportada no mundo todo. (Disponível em: <https://www.unodc.org/toc/en/crimes/organized-crime.html> Acesso em 05 abr. 2014).

57 DAVIN, João. A Criminalidade organizada transnacional: a cooperação judiciária e policial na UE. Coimbra: Almedina, 2007. p. 110.

58 DAVIN, João. A Criminalidade organizada transnacional: a cooperação judiciária e policial na UE. Coimbra: Almedina, 2007. p. 113-114.

59 DAVIN, João. A Criminalidade organizada transnacional: a cooperação judiciária e policial na UE. Coimbra: Almedina, 2007. p. 114.

${ }^{60}$ SILVA SÁNCHEZ, Jesús María. La expansión del Derecho penal: aspectos de la Política criminal em las sociedades postindustriales. Madrid: Edisofer, 2011. p. 91. 
Revista Eletrônica de Direito Processual - REDP.

Rio de Janeiro. Ano 12. Volume 19. Número 1. Janeiro a Abril de 2018

Periódico Quadrimestral da Pós-Graduação Stricto Sensu em Direito Processual da UERJ

Patrono: José Carlos Barbosa Moreira (in mem.). ISSN 1982-7636. pp. 35-61 www.redp.uerj.br

mercados e está envolvida também com a corrupção de funcionários públicos e governantes ${ }^{61}$.

Essa construção conceitual deixa evidente o contraste entre o alto poder técnico e operacional utilizado pela criminalidade transnacional e aqueles disponíveis ao Estado para a persecução penal, impossibilitando uma resposta rápida e concreta a esse tipo de crime ${ }^{62}$. Isso representa uma rachadura no sistema criminal que tem como consequência: violação de direitos e garantias democráticas em prol do utilitarismo da "luta" contra o crime “comum" e redução de custos do sistema de justiça penal ${ }^{63}$. Para Alberto Silva Franco:

Se nenhum adequado equacionamento for adotado para o controle da criminalidade dos poderosos, corre-se o sério risco, a curto prazo, de partir-se para um Direito Penal despótico, desligado dos princípios e das garantias próprias do Direito Penal de um Estado constitucionalmente democrático. $^{64}$

Contudo, apesar dessas construções conceituais apresentarem características importantes para compreender o fenômeno, ainda se limita a um tipo de criminalidade transnacional, que é a organizada. Assim, revela-se uma pequena confusão terminológica associando automaticamente a criminalidade transnacional àquela que é além de transnacional, organizada.

Assim, importante destacar que criminalidade transnacional é gênero que pode se manifestar em duas espécies: organizada e "comum". Por tal razão, dentro do conceito do gênero criminalidade transnacional se enquadra qualquer atividade criminosa cuja dinâmica envolva, em qualquer etapa de realização da conduta material, necessariamente, mais de um país. A partir do gênero, as duas espécies possuem características diversas que as diferem de forma substancial.

A primeira delas, denominada criminalidade transnacional organizada apresenta características já delimitadas no começo desse capítulo, e que em muitos casos trata-se de uma organização criminosa que alcança, para melhor rendimento das suas atividades

\footnotetext{
${ }^{61}$ SILVA SÁNCHEZ, Jesús María. La expansión del Derecho penal: aspectos de la Política criminal em las sociedades postindustriales. Madrid: Edisofer, 2011. p. 91.

${ }^{62}$ FRANCO, Alberto Silva. Globalização e a criminalidade dos poderosos. Revista Brasileira de Ciências Criminais, ano 8, São Paulo, 2000. p. 121.

${ }^{63}$ HASSEMER, Weinfried. Perspectivas del Derecho penal futuro. p. 37-41. Revista Penal, v.1, jan., HuelvaSalamanca-Castilla-La Mancha, 1998. p. 37.

${ }^{64}$ FRANCO, Alberto Silva. Globalização e a criminalidade dos poderosos. Revista Brasileira de Ciências Criminais, ano 8, São Paulo, 2000. p. 121.
} 
Revista Eletrônica de Direito Processual - REDP.

Rio de Janeiro. Ano 12. Volume 19. Número 1. Janeiro a Abril de 2018

Periódico Quadrimestral da Pós-Graduação Stricto Sensu em Direito Processual da UERJ

Patrono: José Carlos Barbosa Moreira (in mem.). ISSN 1982-7636. pp. 35-61 www.redp.uerj.br

ilícitas, o patamar transnacional. Mas também pode se dar a partir da interação entre diferentes organizações criminosas nacionais que para viabilizar a atividade transnacional, cooperam entre si. Isso é bastante típico no caso de grandes cartéis de drogas, que envolvem uma cadeia complexa de agentes criminosos, ou esquemas de lavagem de dinheiro, entre outros.

Por outro lado, a denominada criminalidade transnacional comum, é aquela que, embora seja transnacional (por envolver no seu iter criminis algum outro país), caracterizase por ter uma estrutura muito mais simples e atividades menos rentáveis. Normalmente situada nas faixas de fronteira seca $^{65}$, onde a limitação e controle entre os países fronteiriços é pequena ou inexistente, lidam com crimes mais "comuns", como pequenos contrabandos ou tráfico de drogas e armas, extorsão mediante sequestro e fraudes gerais, mas principalmente, embora possam existir quadrilhas especializadas ou apenas concurso de pessoas, não possuem uma estrutura muito complexa.

Ilustrativamente, o Brasil, tem limites fronteiriços com Guiana Francesa, Suriname, Guiana, Venezuela, Colômbia, Peru, Bolívia, Paraguai, Argentina e Uruguai, representando milhares de quilômetros potencialmente favoráveis ao desenvolvimento de atividades criminosas transnacionais. O caso de Foz do Iguaçu é bastante icônico, pois trata-se de uma fronteira entre três países (Brasil, Paraguai e Argentina), com intensa atividade ilícita, desde a mais sofisticada à mais simples, organizada, ou não, mas normalmente transnacionais.

Diante desse panorama, como é que os órgãos envolvidos na persecução penal conseguem coletar dados para serem utilizados no processo penal? Como a prova colhida em um país poderá ser acolhida ordenamento jurídico diverso?

Atualmente é nesse ponto de intersecção que se encontra a cooperação jurídica internacional em matéria penal, resultado da interação entre Estados para enfrentamento da dinâmica criminal transnacional e internacional no contexto contemporâneo da globalização. De fato, a cooperação jurídica internacional representa, no paradigma da contemporaneidade, a ferramenta à disposição dos atores processuais para garantir a persecução penal dentro do escopo democrático do devido processo penal, cumprindo assim o duplo processo de fornecer limites ao Estado-acusação ao mesmo tempo em que garante direitos fundamentais para o sujeito acusado de um crime.

\footnotetext{
${ }^{65}$ Faixas fronteiriças sem limitação natural (rio, montanha, etc.) cuja linha de fronteira é "invisível".
} 


\section{A cooperação internacional como instrumento fundamental da persecução penal contemporânea.}

Embora existam registros de acordos de extradição desde a antiguidade ${ }^{66}$, o "estatuto global de solidariedade interetática e garantias (formais e substanciais)",67, como Polimeni se refere à cooperação internacional, é um instituto jurídico consideravelmente recente, razão pela qual alguns contornos conceituais ainda estão para se sedimentarem. E por lidar com transformações nas interações entre países em contraponto a uma lógica jurídica clássica (ressignificações sobre a ideia de soberania, território, fronteira, etc.), ainda a cooperação é um tema com muitas pautas científicas para desenvolvimento, especialmente no que diz respeito ao âmbito do processo penal.

Atualmente se observa um maior desenvolvimento da cooperação internacional nas relações estabelecidas diretamente por outros atores além dos mecanismos tradicionais (carta rogatória ou via diplomática), como, por exemplo, o auxílio direto e também os canais internacionais de comunicação entre órgãos administrativos (CVM, CADE, Receita Federal, Banco Central, entre outros). Nesse sentido, há também as diversas formas de interação internacional de agências intergovernamentais como a Finantial Action Task Force - FATF ${ }^{68}$ e o Egmont Group ${ }^{69}$, que já possuem ampla atuação global, inclusive no Brasil $^{70}$. Esse fenômeno responde aos anseios de maior celeridade e fluidez na informação

\footnotetext{
${ }^{66}$ Um dos mais antigos tratados internacionais, por volta do século XIII a.c., entre os impérios Egípcio e Hitita, prevê acordos de extradição de prisioneiros, acordos militares e divisão territorial de influência de cada uma das partes envolvidas. (EVANS, Malcolm D. International Law. United Kingdom: Oxford University Press, 2014. p. 5).

${ }^{67}$ CERVINI, Raúl; TAVARES, Juarez. Princípios de Cooperação Judicial Penal Internacional no Protocolo do MERCOSUL. São Paulo: Revista dos Tribunais, 2000. p. 50.

${ }^{68}$ Criada em 1989, é uma agência intergovernamental que tem por objetivo estabelecer padrões e promover a efetiva implementação de normas, regulamentação e operação de medidas para o combate à lavagem de dinheiro, ao financiamento do terrorismo e a outras ameaças relacionadas à integridade do sistema financeiro internacional. (Disponível em <http://www.fatf-gafi.org/pages/aboutus/> Acesso em 16 out. 2014).

69 Decorrente da reunião de Unidades de Inteligência Financeira (Financial Intelligence Units - FIUs) ocorrida no Palácio de Egmont Arenberg (Bélgica), reconhecendo a necessidade de cooperação internacional para o combate à lavagem de dinheiro e ao financiamento do terrorismo, estabeleceram uma rede informal de intercâmbio entre informações e de cooperação internacional. A representação brasileira nas reuniões se dá pelo COAF, órgão de inteligência financeira nacional. (Disponível em <http://www.egmontgroup.org/> Acesso em 16 out. 2014).

${ }^{70}$ Especificamente nesse ponto, no julgamento da Ação Penal 470 (Caso Mensalão), a conclusão dos Ministros do Supremo Tribunal Federal quanto a prática do crime de lavagem de dinheiro pelos réus levou em consideração as recomendações do Grupo Egmont e da FATF/Gafi.
} 
Revista Eletrônica de Direito Processual - REDP.

Rio de Janeiro. Ano 12. Volume 19. Número 1. Janeiro a Abril de 2018

Periódico Quadrimestral da Pós-Graduação Stricto Sensu em Direito Processual da UERJ

Patrono: José Carlos Barbosa Moreira (in mem.). ISSN 1982-7636. pp. 35-61 www.redp.uerj.br

prestada por meio da cooperação, proporcionando efetividade no cumprimento das medidas com repercussão jurídica.

Assim, embora seja inegável o reconhecimento da cooperação jurídica internacional como ferramenta necessária no mundo globalizado, os contornos conceituais básicos ainda são heterogêneos. Por tal razão, se faz necessário um esboço dos conceitos brasileiros em contrapartida aos entendimentos estrangeiros acerca da matéria.

A cooperação jurídica internacional consiste, segundo Bechara, no "conjunto de atos que regulamenta o relacionamento entre dois Estados ou mais, ou ainda entre Estados e Tribunais Internacionais, tendo em vista a necessidade gerada a partir das limitações territoriais de soberania" ${ }^{\not 1}$. Observa-se que o autor utiliza como eixo central do conceito a ideia de que a cooperação (conjunto de atos) regulamenta a relação entre Estados, estabelecendo a premissa de que a cooperação regula "algo" (relação entre Estados).

Embora bastante valoroso o enfoque dado, revelando tratar-se primordialmente de relação estatal e não entre indivíduos, ao que tudo indica, a cooperação jurídica internacional se constitui em produto ou resultado da relação entre os Estados e não regulamentadora dessa relação. De maneira geral, a regulamentação da cooperação se dá por meio de acordos internacionais (lato sensu) ou de relações diplomáticas, que se fundamentam na relação entre os Estados.

Para Carolina Yumi, a cooperação jurídica internacional consiste no "intercâmbio entre Estados soberanos, destinando-se à segurança e à estabilidade das relações transnacionais" ${ }^{\text {72 }}$. Destacando a complexidade de desenvolvimento teórico acerca do significado de "Estado Soberano", de fato, só é possível estabelecer mecanismos de cooperação internacional entre Estados politicamente organizados e que gozam de algum nível de soberania, afinal, seria inconcebível a possibilidade de, por exemplo, utilizar mecanismos de cooperação internacional - principalmente em matéria penal - com o ISIS $^{73}$. Por outro lado, atualmente existem acordos de cooperação com Hong Kong (região

\footnotetext{
${ }^{71}$ BECHARA, Fábio Ramazzini. Cooperação jurídica internacional em matéria penal: eficácia da prova produzida no exterior. São Paulo: Saraiva, 2011. p. 42.

${ }_{72}$ SOUZA, Carolina Yumi de. Cooperação jurídica internacional em matéria penal: considerações práticas. p. 297-325. Revista Brasileira de Ciências Criminais, março-abril de 2008, no 71. São Paulo, 2008. p. 300.

${ }^{73}$ Tendo origem em um grupo dissidente da al Qaeda, atualmente chefiada por Abu Bakr al-Baghdadi, é o Estado Islâmico no Iraque e o Levante e Estado Islâmico (Islamic State in Iraq and the Levant and Islamic State - ISIS), expandiu seus domínios em diversos territórios na região da Syria e Iraque. (Disponível em <http://edition.cnn.com/2014/08/08/world/isis-fast-facts/> Acesso em 16 out. 2014).
} 
Revista Eletrônica de Direito Processual - REDP.

Rio de Janeiro. Ano 12. Volume 19. Número 1. Janeiro a Abril de 2018

Periódico Quadrimestral da Pós-Graduação Stricto Sensu em Direito Processual da UERJ

Patrono: José Carlos Barbosa Moreira (in mem.). ISSN 1982-7636. pp. 35-61

www.redp.uerj.br

especial administrativa da República Popular da China) ${ }^{74}$, além do caso da Ucrânia, país que recentemente teve a sua ordem político-soberana abalada $^{75}$, mas que possui acordo vigente de assistência jurídica mútua (Mutual Legal Assistance Treaty - MLAT) com o Brasil desde 2006 (Decreto $\left.\mathrm{n}^{\mathrm{o}} 5.984 / 06\right)^{76}$, além do caso mais recente da Venezuela.

Todavia, parece mais adequado, no que diz respeito à cooperação jurídica em matéria penal, principalmente quando gera efeitos probatórios criminais, a adoção da concepção de Estado Constitucional de Direito ${ }^{77}$. Isso tendo em vista a viabilidade da tutela dos direitos e garantias fundamentais na relação entre Estados materializada pela utilização da cooperação jurídica internacional em matéria penal.

Alterando o eixo central da conceituação, Denise Abade afirma que cooperação jurídica internacional em matéria criminal é o "conjunto de medidas e mecanismos pelos quais órgãos competentes dos Estados solicitam e prestam auxílio recíproco para realizar, em seu território, atos pré-processuais ou processuais que interessem à jurisdição estrangeira na esfera criminal”78. Nota-se uma virada conceitual, pois focada não mais no relacionamento entre Estados, passando a enfatizar as medidas adotadas, com base na

74 Disponível em <http://portal.mj.gov.br/main.asp?View=\{D6765F39-FE1C-4810-A6EF60E071C1DF02 $\} \&$ BrowserType=IE \&LangID $=$ pt-br\&params=itemID\%3D\%7BC0B76B8E-55FE-4A629695-42A980076E66\%7D\%3B\&UIPartUID=\%7B2868BA3C-1C72-4347-BE11-A26F70F4CB26\%7D>

Acesso em 16 out. 2014.

${ }^{75}$ Em razão da opção do presidente Viktor Yanukovich por um alinhamento pró-Rússia em detrimento aos antigos rumos (pró-Europa), deram início manifestações que foram reprimidas com extrema violência. A instabilidade interna repercutiu no cenário internacional quando o presidente da Rússia, Vladimir Putin apoiou militarmente, com o envio de tropas para a fronteira da Criméia. (Disponível em <http://www1.folha.uol.com.br/infograficos/2014/03/82265-entenda-tudo-sobre-a-crise-na-ucrania.shtml> Acesso em 17 out. 2014).

${ }^{76}$ Acordo de Assistência Judiciária em matéria penal entre o Governo da República Federativa do Brasil e o Governo da Ucrânia. p. 637-645. In: MINISTÉRIO DA JUSTIÇA. Manual de cooperação jurídica internacional e recuperação de ativos. Brasília: Ministério da Justiça, 2012.

${ }^{77}$ Na lição do Prof. Luciano Feldens, o Estado Constitucional de Direito se caracteriza por " $(i)$ um modelo de Estado e Constituição que não abre espaço nem a um legislador arbitrário, dono absoluto de suas decisões legiferantes, nem a um juiz onipotente que pretenda substituir, sem mais, o desenvolvimento legislativo da política [...]; (ii) um modelo de Estado dotado de uma Constituição rígida, normativa, que rejeita o produto legislativo que se coloque em relação de contraste material com suas linhas essências; mas também um modelo de Estado que permite uma contínua explicitação da Constituição através de um processo político democrático, aberto à renovação dos anseios sociais; (iii) e por utilizar uma metáfora que fundamenta o fenômeno da mutação constitucional: um modelo de Estado e Constituição sem atavismos, em que um texto aprovado no passado não condicione absolutamente a geração futura; um modelo de Estado e Constituição, pois, onde os vivos possam ser governados pelos vivos." (FELDENS, Luciano. Direitos fundamentais $e$ Direito Penal: a Constituição Penal. Porto Alegre: Livraria do Advogado, 2012. p. 36).

78 ABADE, Denise Neves. Direitos fundamentais na cooperação jurídica internacional: extradição, assistência jurídica, execução de sentença estrangeira e transferência de presos. São Paulo: Saraiva, 2013. p. 27. 
Revista Eletrônica de Direito Processual - REDP.

Rio de Janeiro. Ano 12. Volume 19. Número 1. Janeiro a Abril de 2018

Periódico Quadrimestral da Pós-Graduação Stricto Sensu em Direito Processual da UERJ

Patrono: José Carlos Barbosa Moreira (in mem.). ISSN 1982-7636. pp. 35-61 www.redp.uerj.br

reciprocidade, abrangendo ainda atos de toda a persecução penal ${ }^{79}$ (pré-processual ou processual $^{80}$ ).

Para o processo penal, esse conceito apresenta balizas mais relevantes, pois foca nos reflexos concretos da relação entre os Estados, a partir dos mecanismos de cooperação. Além do mais, como já exposto brevemente, atualmente a cooperação jurídica internacional tem se expandido para áreas que extrapolam o círculo fechado da jurisdição ou do processo -, muitas vezes se estabelecendo entre agências administrativas ou órgãos intergovernamentais. Nem por isso deixa de ter relevância para o processo penal, afinal, os atos administrativos ou investigativos posteriormente poderão ser utilizados como prova processual.

De forma mais completa, o conceito apresentado por Raúl Cervini, considerado um dos precursores do estudo da cooperação internacional na América Latina, a define como:

[...] conjunto de atividades processuais (cuja projeção não se esgota nas simples formas), regulares (normais), concretas e de diverso nível, cumpridas por órgãos jurisdicionais (competentes) em matéria penal, pertencentes a distintos Estados soberanos, que convergem (funcional e necessariamente) em nível internacional, na realização de um mesmo fim, que não é senão o desenvolvimento (preparação e consecução) de um processo (principal) da mesma natureza (penal), dentro de um estrito marco de garantias conforme o diverso grau e projeção intrínseco do auxílio requerido $^{81}$. (grifo do autor)

Embora as balizas conceituais apresentadas pelo Professor Cervini sejam bastante completas, parte de uma diferenciação entre atos de cooperação judicial e extrajudicial (administrativa ou policiais), mas dando predileção ao aspecto jurisdicional da cooperação. Tem-se que atualmente essa diferenciação não tem mais muito significado, já que o foco principal deve ser na finalidade das medidas adotas e não nos atores que a promovem.

Um estudo realizado no âmbito europeu aponta que a distinção clássica entre cooperação judicial e policial (administrativa), além de não ser essencial, e em alguns

\footnotetext{
${ }^{79}$ WEBER, Patrícia Núñez. A Cooperação jurídica Internacional em Medidas Processuais Penais. Porto Alegre: Verbo Jurídico, 2011. p. 53.

${ }^{80}$ ARAUJO, Nadia. A importância da cooperação jurídica internacional para a atuação do Estado brasileiro no plano interno e internacional. p. 33-50. In: MINISTÉRIO DA JUSTIÇA. Manual de cooperação jurídica internacional e recuperação de ativos. Brasília: Ministério da Justiça, 2012. p. 34.

${ }^{81}$ CERVINI, Raúl; TAVARES, Juarez. Princípios de Cooperação Judicial Penal Internacional no Protocolo do MERCOSUL. São Paulo: Revista dos Tribunais, 2000. p. 51.
} 
Revista Eletrônica de Direito Processual - REDP.

Rio de Janeiro. Ano 12. Volume 19. Número 1. Janeiro a Abril de 2018

Periódico Quadrimestral da Pós-Graduação Stricto Sensu em Direito Processual da UERJ

Patrono: José Carlos Barbosa Moreira (in mem.). ISSN 1982-7636. pp. 35-61

www.redp.uerj.br

casos inexistentes, por vezes pode ter caráter contraproducente ${ }^{82}$. Nesse aspecto, a

cooperação internacional em matéria criminal deve ser conceituada a partir de um padrão que visa a finalidade da medida em detrimento dos atores, por si só ${ }^{83}$.

Neste diapasão, observa-se a participação de diversos atores envolvidos em diversas finalidades, como esquematizado no quadro abaixo extraído da obra de Gert Vermeulen:

\begin{tabular}{|c|c|c|c|c|c|c|}
\hline \multicolumn{7}{|c|}{ Finality versus nature of authority } \\
$\begin{array}{c}\text { Finality } \\
\text { Auth }\end{array}$ & Judicial & Policy & Custom & $\begin{array}{c}\text { Admini- } \\
\text { strative }\end{array}$ & Central & $\begin{array}{c}\text { Intelli- } \\
\text { gence }\end{array}$ \\
\hline $\begin{array}{c}\text { Criminal } \\
\text { justice }\end{array}$ & $\mathrm{x}$ & $\mathrm{x}$ & $\mathrm{x}$ & $\mathrm{x}$ & $\mathrm{x}$ & $\mathrm{x} ?$ \\
\hline $\begin{array}{c}\text { Civil } \\
\text { justice }\end{array}$ & $\mathrm{x}$ & & & & & \\
\hline $\begin{array}{c}\text { Adminis } \\
\text { trative }\end{array}$ & & $\mathrm{x}$ & $\mathrm{x}$ & $\mathrm{x}$ & & $\mathrm{x}$ \\
\hline
\end{tabular}

O enfoque dado para a finalidade da cooperação ao invés do ator envolvido proporciona a compreensão mais delimitada da função da cooperação, impedindo, por exemplo, que atores que não estejam relacionados com a persecução penal, possam realizar cooperação, como é o caso das agências de inteligência ${ }^{85}$. Por evidente, as agências de inteligência (ABIN, CIA, NSA, etc.), embora possuam canais próprios de cooperação, sua atividade é totalmente alheia ${ }^{86}$ à finalidade da persecução penal.

82 VERMEULEN, Gert; BONDT, Wendy De; RYCKMAN, Charlotte. (eds) Rethinking international cooperation in criminal matters in the EU: moving beyond actors, bringing logic back, footed in reality. IRCIP research series, volume 42. Antwerpen: Maklu, 2012. p. 63.

83 VERMEULEN, Gert; BONDT, Wendy De; RYCKMAN, Charlotte. (eds) Rethinking international cooperation in criminal matters in the EU: moving beyond actors, bringing logic back, footed in reality. IRCIP research series, volume 42. Antwerpen: Maklu, 2012. p. 63.

84 VERMEULEN, Gert; BONDT, Wendy De; RYCKMAN, Charlotte. (eds) Rethinking international cooperation in criminal matters in the EU: moving beyond actors, bringing logic back, footed in reality. IRCIP research series, volume 42. Antwerpen: Maklu, 2012. p. 63.

85 VERMEULEN, Gert; BONDT, Wendy De; RYCKMAN, Charlotte. (eds) Rethinking international cooperation in criminal matters in the EU: moving beyond actors, bringing logic back, footed in reality. IRCIP research series, volume 42. Antwerpen: Maklu, 2012. p. 64.

${ }^{86}$ É exatamente esse o entendimento do Superior Tribunal de Justiça, materializado no julgamento em 2011, pela $5^{\text {a }}$ Turma, do habeas corpus $\mathrm{n}^{\circ} 149.250 / \mathrm{SP}$ que anulou todas as provas produzidas por agentes da ABIN e ex-agente do SNI, no desenrolar da "Operação Satiagraha", pois conforme a ementa: "1. Uma análise detida dos 11 (onze) volumes que compõem o HC demonstra que existe uma grande quantidade de provas aptas a confirmar, cabalmente, a participação indevida, flagrantemente ilegal e abusiva, da ABIN e do investigador particular contratado pelo Delegado responsável pela chefia da Operação Satiagraha. 2. Não há se falar em compartilhamento de dados entre a ABIN e a Polícia Federal, haja vista que a hipótese dos autos não se enquadra nas exceções previstas na Lei nº 9.883/99.” (STJ - Rel. Min. Adilson Vieria Macabu, T 5, julgado em 07/06/2011). 
Em síntese, fica evidente, após a exposição dos diferentes enfoques na conceituação da cooperação jurídica internacional a falta de uniformidade. Contudo, buscando-se a construção geral para a compreensão do instituto no processo penal contemporâneo, é possível fixar algumas balizas conceituais comum e que serão úteis para o aprofundamento, partindo sempre da finalidade da cooperação.

Desta forma, a cooperação jurídica internacional em matéria penal consiste na (i) interação entre diferentes Estados, (ii) fundada na voluntariedade e reciprocidade, (iii) utilizando-se de mecanismos de comunicação ou execução transnacionais, (iv) a serviço da persecução penal.

Ao tratar da interação entre diferentes Estados, esse conceito abrange uma importante característica da cooperação internacional atualmente, fundada na relação entre Estados e não entre indivíduos. Embora exista possibilidade de indivíduos conseguirem informações relevantes para o processo penal localizadas em outros países, os acordos de cooperação são firmados entre Estados e são esses acordos que deverão regular, oficialmente à cooperação internacional em matéria penal.

Outra característica que compõe a construção conceitual é a voluntariedade e reciprocidade. Isso porque ao firmarem um acordo internacional, a base normativa será fundada no tratamento recíproco da matéria por envolver países diferentes, além, é claro da voluntariedade de adesão ao pacto.

A forma como se opera na prática a cooperação pode se dar de diferentes formas: auxílio direto carta rogatória extradição, etc. E o avanço de meios tecnológicos poderão também alterar esses exemplos, razão pela qual o que importa compor o conceito geral é que a cooperação se opera por meios de comunicação entre os Estados que podem se dar de diversas formas.

Por fim a característica mais relevante como exposto anteriormente, está assentada na finalidade da cooperação, independentemente dos atores envolvidos, que pode ser um órgão judicial ou não. Vale ainda destacar que alguns órgãos possuem canais direto de comunicação e intercâmbio de dados, o que é um tema bastante complexo e merecedor de análise específica.

Em síntese, limitado ao espaço próprio de um artigo científico, foram traçadas as principais propostas conceituais em torno da cooperação internacional em matéria penal 
além de oferecer um conceito próprio, ciente da natural dinâmica veloz com que esse tema se adapta à realidade contemporânea e por isso em constante aprimoramento. Ademais, ficou assentado que o enfrentamento da criminalidade transnacional só poderá ser efetiva se os Estados integrarem esforços nessa empreitada destacando a importância da cooperação jurídica internacional como mecanismo que concretiza essa possiblidade equilibrando os anseios da persecução penal permitindo a colheita de elementos probatórios ou executórios desde critérios garantidores dos diretos do acusado.

\section{Considerações Finais:}

O paradigma contemporâneo de intensas transformações reflete diretamente no direito criminal, especialmente na dinâmica daquilo que se denomina criminalidade transnacional. De fato, o fenômeno da globalização é uma das responsáveis por abrir novas possibilidades para viabilizarem o sucesso do desenvolvimento dessa criminalidade, que em contrapartida à ação estatal de repressão, está bastante mais avançada.

Embora a preocupação internacional seja voltada principalmente para a criminalidade transnacional organizada, a criminalidade transnacional "comum" também é um fenômeno que está diretamente relacionado com a contemporaneidade e que apresenta dificuldades para a persecução penal. E para essa constatação, é relevante a demarcação conceitual de cada um dos institutos, além da diferença em relação a criminalidade internacional, que possui em sem cerne características bastante diversas.

Independentemente da manifestação (comum, organizada ou internacional), a persecução penal contemporânea se dará de forma efetiva desde a cooperação entre os países, razão pela qual conceituar os fundamentos da cooperação é relevante. Por tal motivo, no presente artigo foram abordadas as principais balizas conceituais com o objetivo de fornecer a compreensão geral do tema e servir para novas pautas de pesquisa.

Longe de ser um tema esgotado, a cooperação internacional tem se mostrado cada vez mais carente de análises de seus fundamentos e efeitos, ao mesmo tempo em que já é bastante utilizada pelos Estados. Isso pode representar consideráveis prejuízos no futuro, 
Revista Eletrônica de Direito Processual - REDP.

Rio de Janeiro. Ano 12. Volume 19. Número 1. Janeiro a Abril de 2018

Periódico Quadrimestral da Pós-Graduação Stricto Sensu em Direito Processual da UERJ

Patrono: José Carlos Barbosa Moreira (in mem.). ISSN 1982-7636. pp. 35-61 www.redp.uerj.br

mas sabe-se que atualmente a cooperação internacional, fundada em acordos internacionais ou na reciprocidade, é a ferramenta que se dispõe para cumprir a dupla tarefa de fornecer elementos para a acusação eficaz e o seu enfrentamento da criminalidade transnacional ao mesmo tempo em que funda o paradigma de garantias do acusado no processo penal.

\section{REFERÊNCIAS BIBLIOGRÁFICAS:}

ABADE, Denise Neves. Direitos fundamentais na cooperação jurídica internacional: extradição, assistência jurídica, execução de sentença estrangeira e transferência de presos. São Paulo: Saraiva, 2013.

Acordo de Assistência Judiciária em matéria penal entre o Governo da República Federativa do Brasil e o Governo da Ucrânia. p. 637-645. In: MINISTÉRIO DA JUSTIÇA. Manual de cooperação jurídica internacional e recuperação de ativos. Brasília: Ministério da Justiça, 2012.

ARAUJO, Nadia. A importância da cooperação jurídica internacional para a atuação do Estado brasileiro no plano interno e internacional. p. 33-50. In: MINISTÉRIO DA JUSTIÇA. Manual de cooperação jurídica internacional e recuperação de ativos. Brasília: Ministério da Justiça, 2012.

BECHARA, Fábio Ramazzini. Cooperação jurídica internacional em matéria penal: eficácia da prova produzida no exterior. São Paulo: Saraiva, 2011.

CANNIZZARO, Enzo. Diritto Internazionale. Torino: G. Giappichell, 2014.

CASSESSE, Antonio. Il sogno dei diritti umani. Milano: Giangiacomo Feltrinelli Editore, 2008.

CASSESSE, Antonio. International Law. New York: Oxford University Press, 2005.

CERVINI, Raúl; TAVARES, Juarez. Princípios de Cooperação Judicial Penal Internacional no Protocolo do MERCOSUL. São Paulo: Revista dos Tribunais, 2000.

COSTA, José de Faria. Direito Penal e Globalização: reflexões não locais e pouco globais. Coimbra: Coimbra Editora, 2010.

DAVIN, João. A Criminalidade organizada transnacional: a cooperação judiciária e policial na UE. Coimbra: Almedina, 2007.

EVANS, Malcolm D. International Law. United Kingdom: Oxford University Press, 2014. 
Revista Eletrônica de Direito Processual - REDP.

Rio de Janeiro. Ano 12. Volume 19. Número 1. Janeiro a Abril de 2018

Periódico Quadrimestral da Pós-Graduação Stricto Sensu em Direito Processual da UERJ

Patrono: José Carlos Barbosa Moreira (in mem.). ISSN 1982-7636. pp. 35-61

www.redp.uerj.br

FELDENS, Luciano. Direitos fundamentais e Direito Penal: a Constituição Penal. Porto

Alegre: Livraria do Advogado, 2012.

FIGUEIREDO DIAS, Jorge de. Direito Penal: parte geral. Coimbra: Coimbra editora, 2012.

FRANCO, Alberto Silva. Globalização e a criminalidade dos poderosos. Revista Brasileira de Ciências Criminais, ano 8, São Paulo, 2000.

GIACOMOLLI, Nereu. O devido processo penal: abordagem conforme a Constituição Federal e o Pacto de São José da Costa Rica. São Paulo: Atlas, 2014.

GIDDENS, Anthony. As consequências da modernidade. São Paulo: Editora Unesp, 1991.

GIDDENS, Anthony. Mundo em descontrole: o que a globalização está fazendo de nós. Rio de Janeiro: Record, 2011.

HABERMAS, Jürgen. A constelação pós-nacional. São Paulo: Littera Mundi, 2001.

HASSEMER, Weinfried. Perspectivas del Derecho penal futuro. p. 37-41. Revista Penal, v.1, jan., Huelva-Salamanca-Castilla-La Mancha, 1998.

HELD, David; McGREW, Anthony. Prós e contras da Globalização. Rio de Janeiro: Jorge Hazar Ed., 2001.

JESSUP, Philip C. Direito transnacional. Rio de Janeiro: Editora Fundo de Cultura S/A, 1965.

MORIN, Edgar. Ciência com consciência. Rio de Janeiro: Bertrand Brasil, 2010.

ROBERTSON, Roland. Globalização: teoria social e cultural global. Petrópolis: Editora Vozes, 2000.

ROBINSON, Jeffrey. A Globalização do crime. Rio de Janeiro: Ediouro, 2001

SANTOS, Milton. Por uma outra globalização: do pensamento único à consciência universal. Rio de Janeiro: Record, 2010.

SILVA SÁNCHEZ, Jesús María. La expansión del Derecho penal: aspectos de la Política criminal em las sociedades postindustriales. Madrid: Edisofer, 2011.

SLAUGHTER, Anne-Marie. The New World Order. New Jersey: Princeton University Press, 2004.

SOUSA SANTOS, Boaventura (org.). A Globalização e as Ciências sociais. São Paulo: Cortez, 2011. 
Revista Eletrônica de Direito Processual - REDP.

Rio de Janeiro. Ano 12. Volume 19. Número 1. Janeiro a Abril de 2018

Periódico Quadrimestral da Pós-Graduação Stricto Sensu em Direito Processual da UERJ

Patrono: José Carlos Barbosa Moreira (in mem.). ISSN 1982-7636. pp. 35-61 www.redp.uerj.br

SOUZA, Carolina Yumi de. Cooperação jurídica internacional em matéria penal: considerações práticas. p. 297-325. Revista Brasileira de Ciências Criminais, marçoabril de 2008, nº 71. São Paulo, 2008.

TRINDADE, Antônio A. Cançado. Os Tribunais Internacionais Contemporâneos. Brasília: FUNAG, 2013.

VERMEULEN, Gert; BONDT, Wendy De; RYCKMAN, Charlotte. (eds) Rethinking international cooperation in criminal matters in the EU: moving beyond actors, bringing logic back, footed in reality. IRCIP research series, volume 42. Antwerpen: Maklu, 2012.

WEBER, Patrícia Núñez. A Cooperação jurídica Internacional em Medidas Processuais Penais. Porto Alegre: Verbo Jurídico, 2011. 